\title{
Development of Induced Breeding Technique for Freshwater Fish Gobi, Glossogobius giuris (Hamilton, 1822) Using Pituitary Gland (PG) Extract
}

\author{
Selina Yeasmine ${ }^{1}$, M. Aminur Rahman ${ }^{2^{\star}}$, Md. Sarower-E-Mahfuj ${ }^{2}$, Sonia Sku ${ }^{1}$, \\ Md. Nazmul Hossen ${ }^{1}$, M. Anisur Rahman ${ }^{2^{*}}$ and Md. Fazlul Awal Mollah ${ }^{3}$ \\ ${ }^{1}$ Freshwater Station, Bangladesh Fisheries Research Institute, Mymensingh-2201, Bangladesh. \\ ${ }^{2}$ Department of Fisheries and Marine Bioscience, Faculty of Biological Science and Technology, \\ Jashore University of Science and Technology, Jashore-7408, Bangladesh. \\ ${ }^{3}$ Department of Fisheries Biology and Genetics, Faculty of Fisheries, Bangladesh Agricultural \\ University, Mymensingh-2202, Bangladesh.
}

\begin{abstract}
Authors' contributions
The work was carried out in collaboration among all authors. All authors read, reviewed and approved the final manuscript.

Article Information

DOI: $10.9734 / A R R B / 2021 / v 36 i 130330$

Editor(s):

(1) Paola Angelini, University of Perugia, Italy.

Reviewers:

(1) Ammar M. Al-Aalim, Mosul University, Iraq.

(2) Isra Natheer Alkallak, University of Mosul, Iraq Complete Peer review History: http://www.sdiarticle4.com/review-history/64881
\end{abstract}

Original Research Article

Received 02 November 2020

Accepted 08 February 2021

Published 03 March 2021

\begin{abstract}
This study aimed to establish induced breeding technique of freshwater fish gobi (Glossogobius giuris), using the pituitary gland (PG) extract. Six experiments were conducted at the Department of Fisheries Biology and Genetics, Faculty of Fisheries, Bangladesh Agricultural University, Mymensingh, Bangladesh. First breeding trial was conducted in June using 40, 45, and $50 \mathrm{mg}$ PG $\mathrm{kg}^{-1}$ body weight of the female fish. None of the fish was ovulated in the $1^{\text {st }}$ trial. Two more breeding trials were conducted in July and August, using $6 \mathrm{mg}\left(T_{1}\right), 8 \mathrm{mg}\left(T_{2}\right)$ and $10 \mathrm{mg}\left(T_{3}\right) P G \mathrm{~kg}^{-1}$ body

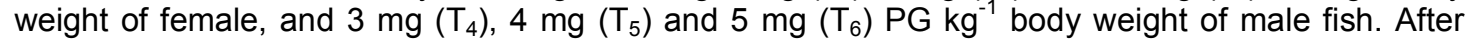
treatment, the ovulation rates were recorded as $56.33 \pm 1.53,82.67 \pm 2.52$ and $75.33 \pm 1.53 \%$ in July and $58.00 \pm 2.65,94.67 \pm 1.53$ and $78.33 \pm 1.53 \%$ in August under the treatments $T_{1}, T_{2}$ and $T_{3}$, respectively. Hatching rates of eggs were observed as $52.00 \pm 4.36,81.67 \pm 3.21$ and $72.33 \pm 6.03 \%$ in July, and $54.67 \pm 3.23,91.67 \pm 3.06$ and $73.67 \pm 5.13 \%$ in August under the $T_{1}, T_{2}$ and $T_{3}$, respectively.
\end{abstract}

*Corresponding author: E-mail: amin2019@just.edu.bd, aminur1963@gmail.com, anis_1963@yahoo.com; 
Hatching time was ranged from 35 to $48 \mathrm{~h}$ and after the absorption of yolk sac (60-72 $\mathrm{h}$ ), they were survived well when fed with tubificid worms and mixed zooplankton. The female treated with the dose of $8 \mathrm{mg} \mathrm{PG} \mathrm{kg}{ }^{-1}$ body weight in August showed the best performance so far as the ovulation, fertilization and hatching rates were concerned, while the single dose of $4 \mathrm{mg} \mathrm{kg}^{-1}$ body weight of $P G$ was found to be effective for male fish in both months. The findings obtained from the present study reveals that induced breeding of $G$. giuris, using PG extract is successful for large scale production of quality seed in captive condition, which would further facilitate towards the aquaculture production and biodiversity conservation of this important fish species to a greater extent.

Keywords: Glossogobius giuris; PG doses; induced breeding; ovulation; fertilization; hatching.

\section{INTRODUCTION}

The freshwater gobi, Glossogobius giuris (Hamilton, 1822), locally known as bele fish, is belonging to the family Gobiidae of the order Perciformes. Under the family Gobiidae, six subfamilies are recognized as Gobiinae, Benthophilinae, Amblyopinae, Gobionellinae, Oxudercinae, and Sicydiinae. It contains 212 genera and 1875 species. Glossogobius giuris is distributed mostly in tropical and subtropical areas, and is native to fresh, marine and brackish water from the Red Sea of East Africa through South Asia and the Indian Ocean to China, Australia and the islands of the Pacific Ocean. It is commonly found in estuarine areas and freshwater including haors, baors, beels, ponds, swamps and rivers throughout Bangladesh, the Punjab, Ceylon, India, Myanmar, Malaysia and the Far East [1-3]. This species is not yet found in IUCN Red list.

Glossogobius giuris, one of the small indigenous species (SIS), has a special preference in the diet of the peoples of Bangladesh because of its special taste, low fat and high protein content, so bele fish is considered as a very important food fish for containing all the nutrients $[4,5]$. About $80 \%$ people of Bangladesh are poor and they depend on SIS (small indigenous species) for their daily supply of animal protein because they are available at reasonable price.

Glossogobius giuris is the only species of genus Glossogobius available in Bangladesh [6] and generally found in canals, ditches and ponds and clear to turbid streams with rock, gravel or sand bottoms. The largest fish has been found to reach a length of $40 \mathrm{~cm}$ (standard length) and the smallest about $3 \mathrm{~cm}$ [7]. Sometimes 2-3 adults fish reach up to a kilogram in weight but normally 10-20 adults weight as kilogram yet one should not be astonished if he finds 50-150 adult individuals fail to make a kilogram. The male and female are known to attain its first maturity at 11.4 and $10.3 \mathrm{~cm}$ length, respectively [8].

In Bangladesh, Glossogobius giuris is very essential food fish, especially to the low-middle class and poor people, because of being relatively cheaper [9]. Different kinds of delicious food items like "jhuri" can be made with the eggs of gobi (G. giuris) fish. Worldwide gobies are considered as a delicacy and precious food in some countries like Italy, India, Burma, Nepal and France [10]. The fish is highly esteemed as food and the price of larger fish is comparatively high than smaller ones. The price of large fresh fish is around $700-800 \mathrm{Tk} . / \mathrm{kg}$. The majority of gobi fishes are being small size that constitute a small fishery in Bangladesh but large size fish (about a foot in length), is notable in some fishery of the southern part of the country [9].

Although gobi fish has been treated as a minor commercial species for capture fishery [11], it contributed $1.93 \%$ of the total catch from Rajdhala beel in Netrakona district of Bangladesh as capture fishery and $1.09 \%$ in an average of the total capture from the river Padma $[9,12]$. However, there is no record on the total catch estimation of $G$. giuris.

As a commercially important fish, the production of $G$. giuris may be increased by culturing in the ponds. In Bangladesh, there are suitable waterbodies for culturing this species with other fishes or can be cultured as a single species for local consumption or exported as a delicious expensive fish. The natural environment of Bangladesh is also very favourable for its culture in captivity. So, it is a suitable candidate for aquaculture as commercial farming. Before bringing this fish in aquaculture, it is needed to gather information about food and feeding behavior, reproductive biology, fecundity, breeding behaviour and season of this fish as well as to develop induced breeding technique for ensuring stockable-sized quality seeds. 
However, no systematic research work has so far been undertaken in Bangladesh on the induced breeding of gobi ( $G$. giuris). Therefore, the present study has been carried out to find out the appropriate induced breeding technique for producing quality seeds. Thus, the present research has practical importance and the findings may be immensely helpful for mass production of quality seeds of this species, which will not only facilitate to aquaculture production but also will save this tasty species from the probable threat of extinction.

\section{MATERIALS AND METHODS}

\subsection{Experimental Site}

The experiment was carried out in the Mini Hatchery and Breeding Complex of the Department of Fisheries Biology and Genetics, Faculty of Fisheries, Bangladesh Agricultural University, Mymensingh and the Government Fish Seed Multiplication Farm, Department of Fisheries, Shambhuganj, Mymensingh, Bangladesh.

\subsection{The Experimental Fish}

The sexually matured broods of gobi (G. giuris) was collected from the Mithamoin haor under Kishoreganj district of Bangladesh and stocked in the ponds for domestication, and were used for breeding purposes. Ready-to-spawn broods were selected and divided into different treatments having 6 females and 6 males in each treatment. All the fish under different treatments were treated with different PG doses. The dry carp pituitary glands (PG), collected from local market (Forhad Enterprise, Mymensingh, Bangladesh) in preserved condition in airtight vials, were used as stimulating agent for induced breeding. The extraction method of $P G$ is given in section 2.5 .

\subsection{Brood Fish Selection}

A day before the breeding trial, good quality and healthy broods of $G$. giuris were caught randomly by reducing the water content from ponds. A total of 36 healthy, good and sexually matured male and female broods (18 males and 18 females) were selected and kept in 3 cisterns for breeding purpose. Selection and proper identification of brood fish is a vital step in any induced breeding technique. Identification of male and female broods was done on the basis of some external features known as secondary sexual characteristics and are shown in Table 1 and Fig. 1. The mature females could easily be identified by their swollen abdomen and round or oval swollen urogenital papillae. On the other hand, the mature males were identified by their flat abdomens and long protruded genital papillae.

\subsection{Conditioning the Brood Fish}

Selected female and male broods were weighed and kept in separate cisterns for 8-10 h before treated with carp PG extract. During conditioning, continuous water flow was provided for aeration to ensure sufficient dissolved oxygen to the stocked brood fishes through porous PVC pipe, which was placed on the top of each cistern.

\subsection{Source of Pituitary Gland (PG) and Preparation of PG extract}

For induction of ovulation, freshly prepared extract of commercially available dry carp pituitary glands (PG, available in the market) was used. To prepare the extract for injection, the required amount of $P G$ was carefully weighed using an electronic balance. The required amount and volume of PG was calculated on the basis of body weight of all the fish of a particular treatment to be injected on a particular day using the standard formulae followed by Mollah et al. [13] as below:

$$
\begin{aligned}
& \text { Weight }(\mathrm{mg}) \text { of required amount of } P G\left(W_{t}\right)= \\
& W_{b} \times P_{t}
\end{aligned}
$$

Where, $W_{b}$ represents the total body weight $(\mathrm{kg})$ of all fishes to be injected; and $P_{t}$ represents the dose in $\mathrm{mg}$ of $\mathrm{PG}$ to be injected $\mathrm{kg}$ body weight under a particular treatment.

The total volume of the extract required was calculated by the following formula:

$$
\text { Vol. of extract }(\mathrm{ml})=\mathrm{W}_{\mathrm{t}} \times 1.0
$$

Where, $W_{t}$ represents the weight of PG $(\mathrm{mg})$; and 1.0 represents the volume of the extract in $\mathrm{ml}$ to be injected $\mathrm{kg}^{-}$body weight of fish.

The weighed PG was homogenized with a small volume of distilled water and the homogenate was carefully transferred to a centrifuge tube by using distilled water to ensure complete transfer. The mixture was centrifuged at $6000 \mathrm{rpm}$ for 6 min. The clear supernatant was transferred to a vial and was made pre-determined volume with 
distilled water. Based on the body weight of the gravid male and female, the required volume of PG extract was loaded in a graduated $1.5 \mathrm{ml}$ hypodermic syringe [13].

\subsection{Experimental Design}

Three trials were conducted during the months of June, July and August to optimize PG doses for the induced breeding of $G$. giuris. In the first trial, nine females were divided into three treatments and designated as $T_{1}, T_{2}$, and $T_{3}$, having three females in each treatment. The females under each treatment were set-up under three replications indicated as $R_{1}, R_{2}$ and $R_{3}$ and kept in separate cisterns. The females under $T_{1}, T_{2}$, and $T_{3}$ were then treated with $P G$ at the dose of 40,45 , and $50 \mathrm{mg} / \mathrm{kg}$ body weight, respectively during the month of June. Another two trials were conducted using $6 \mathrm{mg}\left(\mathrm{T}_{1}\right), 8 \mathrm{mg}\left(\mathrm{T}_{2}\right)$ and $10 \mathrm{mg}$ $\left(T_{3}\right) P G / k g$ body weight of female fish to develop induced breeding technique of $G$. giuris in July and August in 2013. In case of males, the PG doses of 3,4 , and $5 \mathrm{mg} / \mathrm{kg}$ body weight were used in $T_{4}, T_{5}$, and $T_{6}$, respectively.

\subsection{Induction of Ovulation}

\subsubsection{Injecting the PG extract to the experimental fish}

The selected broods of gobi fish were carefully put on a foam/sponge for injecting the PG extract. After that they were wrapped with a soft and soaked cloth and then the extract was injected intramuscularly to the fish under the pectoral fin (Fig. 2). The dose was divided into two volumes (1st dose with $30 \%$ PG and 2 nd dose with $70 \%$ PG) and injected to the females at $6 \mathrm{~h}$ interval. All the males were given a single dose during the 2 nd injection to females. The physical injury and physiological pressure during harvesting, handling, transporting, injecting and holding the brood fish have harmful effects on spawning success. So, during handling, utmost care was taken and optimum water condition was maintained to minimize all kinds of stress.

Table 1. Secondary sexual characteristics used to select mature broods of gobi (G. giuris)

\begin{tabular}{|c|c|c|}
\hline Characters & Female & Male \\
\hline Body size & Smaller than male & Relatively larger than female \\
\hline $\begin{array}{l}\text { Pelvic fins during } \\
\text { breeding season }\end{array}$ & Yellowish in colour & Black-yellowish in colour \\
\hline Genital papilla & $\begin{array}{l}\text { Short, fleshy, oval-shaped and } \\
\text { prominent urogenital papillae }\end{array}$ & $\begin{array}{l}\text { Sharp, straight and protruded } \\
\text { urogenital papillae }\end{array}$ \\
\hline Abdomen & Swollen, bulky and soft abdomen & $\begin{array}{l}\text { Flat and thin abdomen, not bulky like } \\
\text { female }\end{array}$ \\
\hline
\end{tabular}

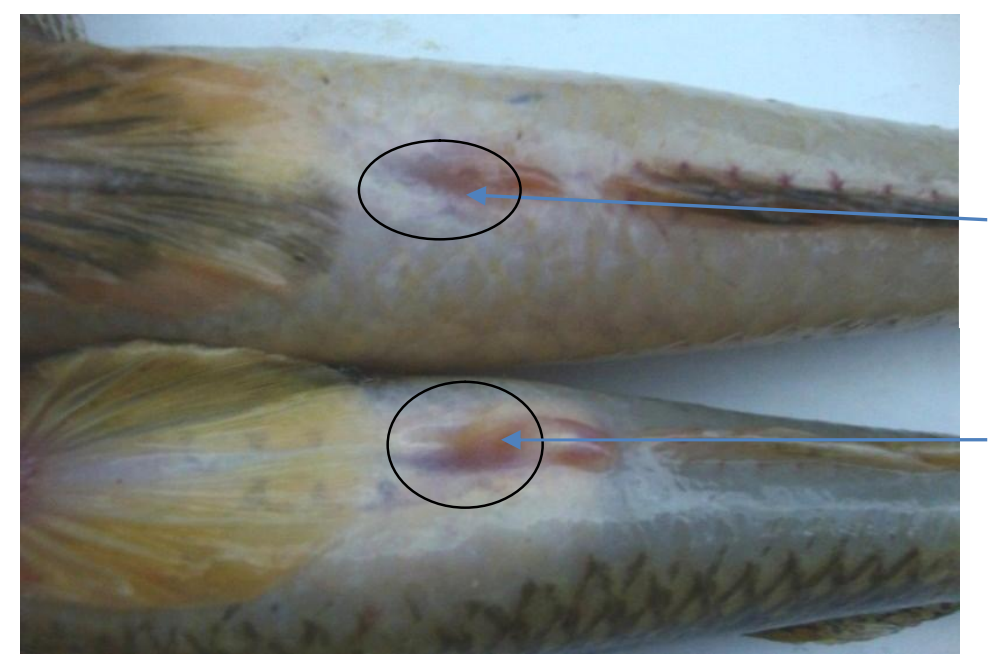

\author{
Male genital \\ papilla \\ Female genital \\ papilla
}

Fig. 1. Genital papillae of gravid male and female gobi (G. giuris) 


\subsubsection{Ovulation, collection of eggs and fertilization with milt}

After injection of $P G$, the males and females were kept in different cisterns for stripping; the female was kept under observation to monitor if they exhibit any change in behaviour. During this period, a very close observation was done to see whether they exhibit pairing or courtship behaviour.

The females were checked every hour after $8 \mathrm{~h}$ of second injection by gently pressing their abdomen to ascertain the ovulation. A fish was considered to be ovulated when there were extrusions of a few eggs upon gentle pressure on the abdomen from anterior to posterior direction.
The females upon ovulation were immediately stripped and eggs from each fish were collected in separate fertilization trays or petri dishes (Fig. 3).

The male could not be stripped for the collection of milt. So, the testes from respective male were dissected out from its body cavity and were macerated in $0.85 \% \mathrm{NaCl}$ solution. To affect and ensure fertilization, the sperm suspension was mixed with eggs by gently stirring with a feather (Fig. 4) and water was added to the egg-sperm mixture to activate the sperms for fertilizing the eggs. Fertilized eggs were then washed several times with clean water to remove the excess milt, blood etc.

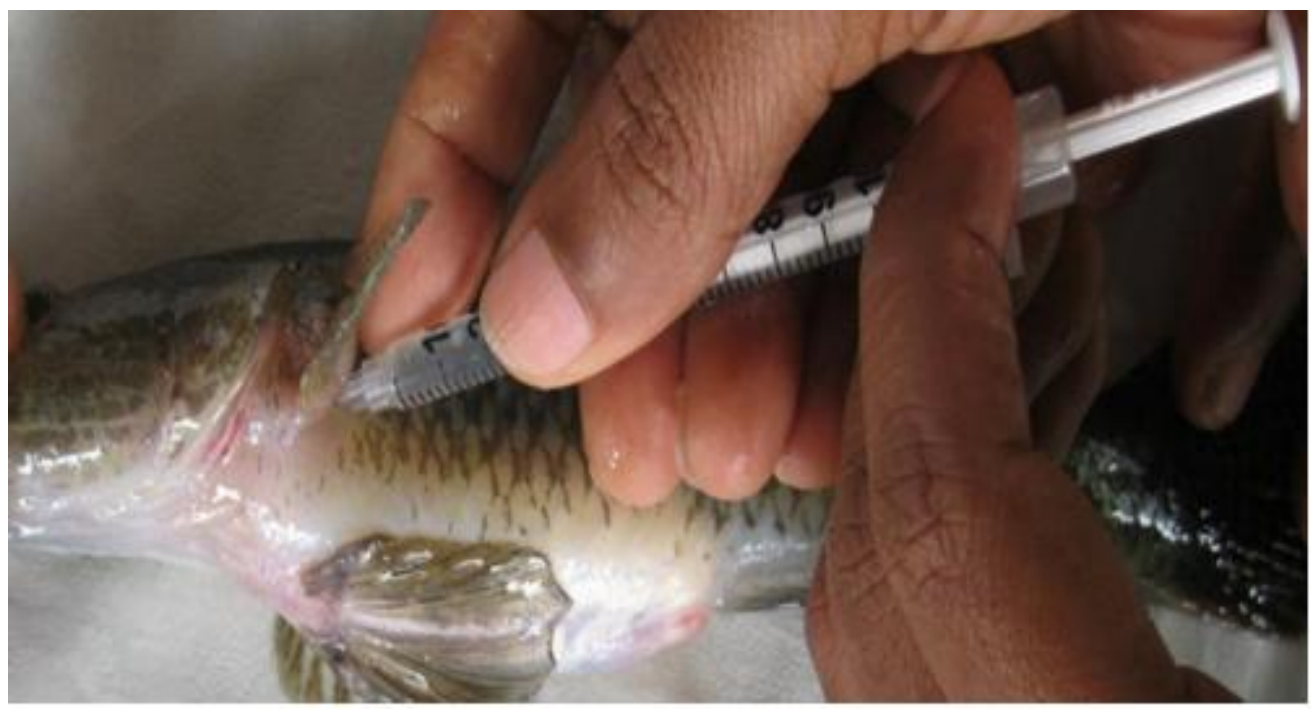

Fig. 2. Injecting PG extract to the female gobi (G. giuris)
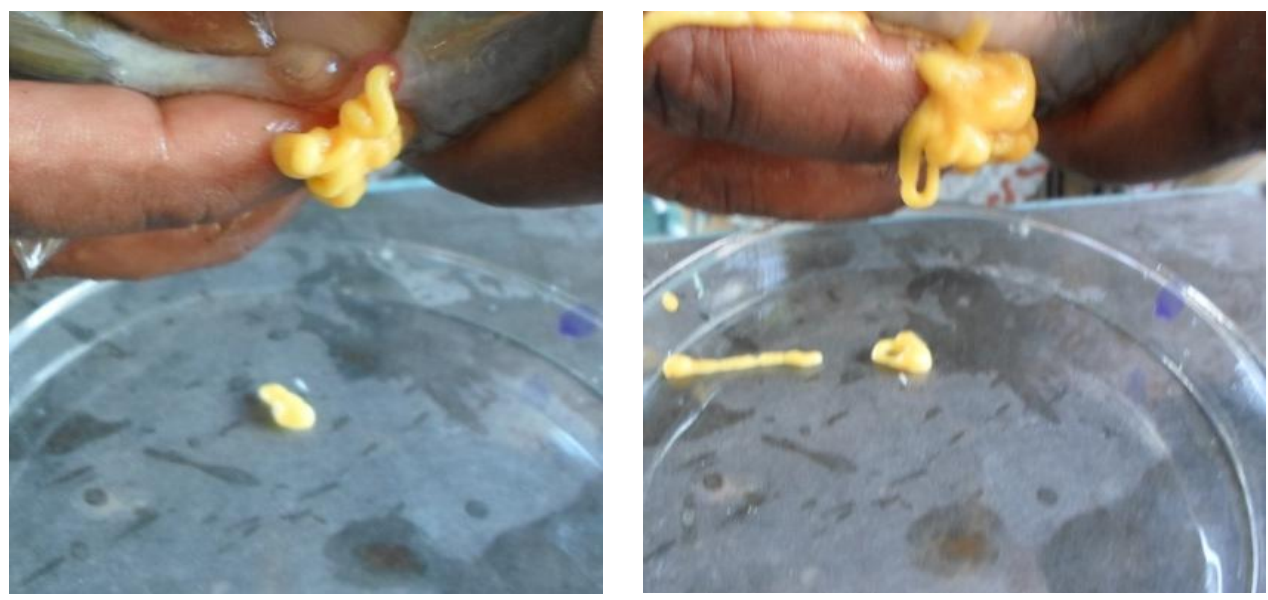

Fig. 3. Stripping of an ovulated female gobi (G. giuris) 


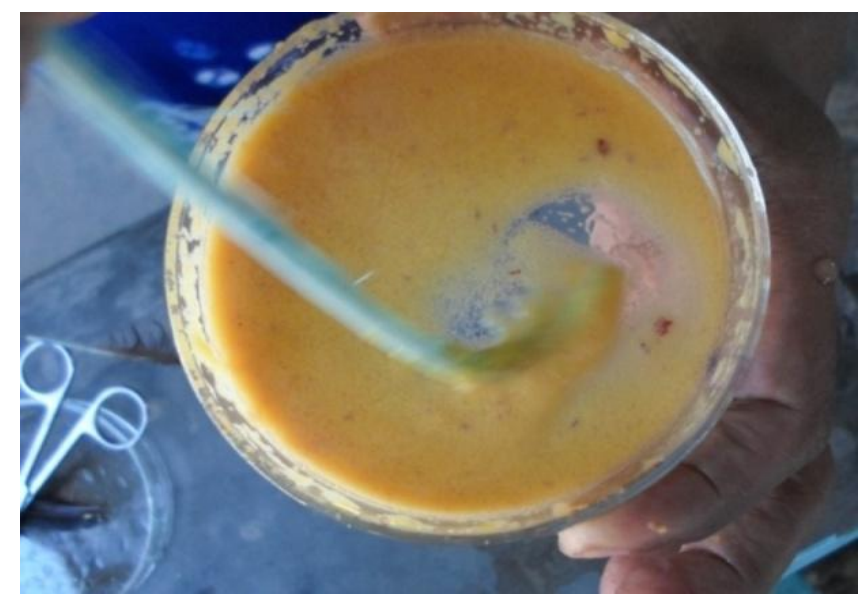

Fig. 4. Fertilization processes of eggs with sperms of gobi (G. giuris)

\subsection{Incubation and Hatching of the Fertilized Eggs}

The fertilized eggs of $G$. giuris were transferred to separate plastic bowls and trays for incubation. All the incubation bowls and trays received gentle shower through porous PVC pipes to ensure adequate aeration. When the fertilized eggs came in contact with water, they were started to swell and became stickier. Dead eggs were removed after every $3 \mathrm{~h}$ and their number was carefully recorded. Upon completion of hatching, the number of hatchlings was also counted and recorded.

\subsection{Determination of Fertilization and Hatching Rates}

A batch of approximately 100 fertilized eggs was placed in each of 3 bowls of $1.25 \mathrm{~L}$ capacity to determine the fertilization and hatching rates of G. giuris. Within $6 \mathrm{~h}$ of incubation, the numbers of fertilized and unfertilized eggs from each bowl were counted based on the colour and appearance of the eggs. The fertilized eggs began to change its size and colour from yellowish to watery and became transparent, while the unfertilized eggs turned opaque and whitish in colour. After completion of hatching, the numbers of larvae of each bowl were counted.

\subsection{Indices of Effectiveness of PG Dose}

The following parameters such as percent ovulation, percent fertilization and percent hatching were recorded as indices of the effectiveness of different PG doses:
Percent ovulation was calculated according to the formula used by Mollah et al. [13] as follows:

$$
\text { Ovulation }(\%)=\frac{\text { No. of fish ovulated }}{\text { Total no. of fish injected }} \times 100
$$

Percentages of fertilization and hatching were calculated using the formulae as below:

$$
\begin{aligned}
& \text { Fertilization }(\%)= \\
& \frac{\text { No. of fertilized eggs }}{\text { Total no. of eggs (fertilized + unfertilized) }} \times 100 \\
& \text { Hatching }(\%)=\frac{\text { No. of hatchlings }}{\text { Total no. of fertilized eggs }} \times 100
\end{aligned}
$$

For calculating the percent fertilization, a number of egg samples (about 50 eggs) were taken from each group and number of fertilized and unfertilized eggs was counted based on the change of colour and size of the eggs under a microscope (NOVEX-Holland).

\subsection{Data Analysis}

Several indices of effectiveness of PG dose were analyzed by MS Excel computer package as descriptive values such as mean and percentage. The statistical data analysis was carried out with the aid of the computer software SPSS version 11.5.

\section{RESULTS}

\subsection{Trial 1}

For standardizing $P G$ dose in female gobi ( $G$. giuris), three different doses of PG 40,45 and 50 $\mathrm{mg} / \mathrm{kg}$ body weight were used in $T_{1}, T_{2}$ and $T_{3}$, 
respectively during the month of June. But no ovulation was occurred under this trial (Table 2).

\subsection{Trial 2 and 3}

Two more trials conducted in July and August showed remarkable differences in effectiveness of three different doses of PG in inducing ovulation. Overall breeding activity including average ovulation, fertilization and hatching rates in all the trials are shown in Table 2 and Fig. 6. At 6-12 h post-injection, the abdomen of female was found to be swollen and soft (Fig. 5).

\subsubsection{Ovulation rate}

Ovulation rate showed marked differences in effectiveness among the three doses with months in inducing ovulation. Females did not respond with PG during the month of June. However, another two breeding trials were conducted in July and August. Among the different treatments, average ovulation rates were recorded to be $56.33 \pm 1.53,82.67 \pm 2.52$ and $75.33 \pm 1.53 \%$ in July and $58.00 \pm 2.65,94.67 \pm 1.53$ and $78.33 \pm 1.53 \%$ in August under the treatments $T_{1}, T_{2}$ and $T_{3}$, respectively. The highest ovulation was observed as $94.67 \pm 1.53 \%$ in August under $T_{2}$, while the lowest value was recorded as $56.33 \pm 1.53 \%$ in July under $T_{1}$. However, ovulation rate under $T_{2}$ was significantly higher $(P<0.05)$ than those of $\mathrm{T}_{3}$ and $T_{1}$ in both July and August (Table 2 and Fig. 6 ). Average latency periods were recorded as 25-35 h in July and August. In case of male fish, the PG dose (4 mg/kg body weight of fish) was found to be satisfactory in both months. During induced breeding, female fishes are mainly considered for the effectiveness of PG hormone, when they attain sexual maturity for breeding purpose. Ovulation occurred easily in captive condition, if appropriate dose of PG hormone is injected to female fish. On the other hand, matured male fishes need little amount of PG doses for the spermination and that's why there is no need the induced breeding data for male fishes.

\subsubsection{Fertilization rate}

Average fertilization rates of eggs were recorded to be $51.33 \pm 1.54,83.33 \pm 3.79$ and $70.33 \pm 3.51 \%$ in July; $53.67 .00 \pm 4.04, \quad 92.33 \pm 2.52$ and $74.00 \pm 3.61 \%$ in August at 6,8 and $10 \mathrm{mg} \mathrm{PG} / \mathrm{kg}$ body weight under the treatments $T_{1}, T_{2}$ and $T_{3}$, respectively. The highest fertilization was recorded as $92.33 \pm 2.52 \%$ in August under $\mathrm{T}_{2}$ whereas the lowest value was recorded as $51.33 \pm 1.54 \%$ in July under $\mathrm{T}_{1}$ (Table 2 and Fig. 6). However, fertilization rate under $T_{2}$ was significantly higher than that of $T_{1}$ and $T_{3}(P<0.05)$ in both July and August.

The embryonic period starts when the egg is fertilized by the sperm and involves a constant synthesis or the building up of those elements that are vital to the normal process in the development of individual. The eggs of $G$. giuris are dissimilar to those of many other fish species so far as the shape is concerned. Soon after fertilization, the eggs were swelled, extended longitudinally, and became adhesive and light brownish to transparent in colour. The swollen and long eggs were attached on some broken parts of earthen pots, which were used as shelters. The unfertilized eggs were whitish in colour and demersal, and also did not change in size and shape. The length of eggs just after fertilization was increased from 0.6 to $3.0 \mathrm{~mm}$ and the width from 0.3 to $0.5 \mathrm{~mm}$, having tendency to attach on substrate or shelters provided. The development of $G$. giuris embryos occurred after $15 \mathrm{~h}$ post-fertilization at $27-29^{\circ} \mathrm{C}$.

\subsubsection{Hatching rate}

Average hatching rate of eggs were observed to be $52.00 \pm 4.36,81.67 \pm 3.21$ and $72.33 \pm 6.03 \%$ in July; $54.67 \pm 3.23,91.67 \pm 3.06$ and $73.67 \pm 5.13 \%$ in August under the treatments $T_{1}, T_{2}$ and $T_{3}$, respectively. The highest hatching was observed as $91.67 \pm 3.06 \%$ in August under $\mathrm{T}_{2}$ and the lowest was recorded as $52.00 \pm 4.36 \%$ in July under $\mathrm{T}_{1}$ (Table 2 and Fig. 6 ). The hatching rate was significantly $(P<0.05)$ higher in $\mathrm{T}_{2}$ than those in all other treatments. Hatching time was ranged from 35 to $48 \mathrm{~h}$ in all treatments. Just after hatching, the larvae moved horizontally near the bottom. After 24-36 h, larvae were moved vertically from bottom close to the water surface and back quickly to the bottom again. Yolk sac absorption of the larvae was started after $40-48 \mathrm{~h}$ of hatching. Finally, after 48-72 $\mathrm{h}$ of hatching, larvae began to swim freely on a horizontal position.

\section{DISCUSSION}

Induced breeding trials of gobi (G. giuris) were conducted to standardize the dose of $P G$ for successful ovulation. Three trials were carried out to develop an induced breeding technique of G. giuris with PG extract. Although many scientists [13-16] carried out experiments on 


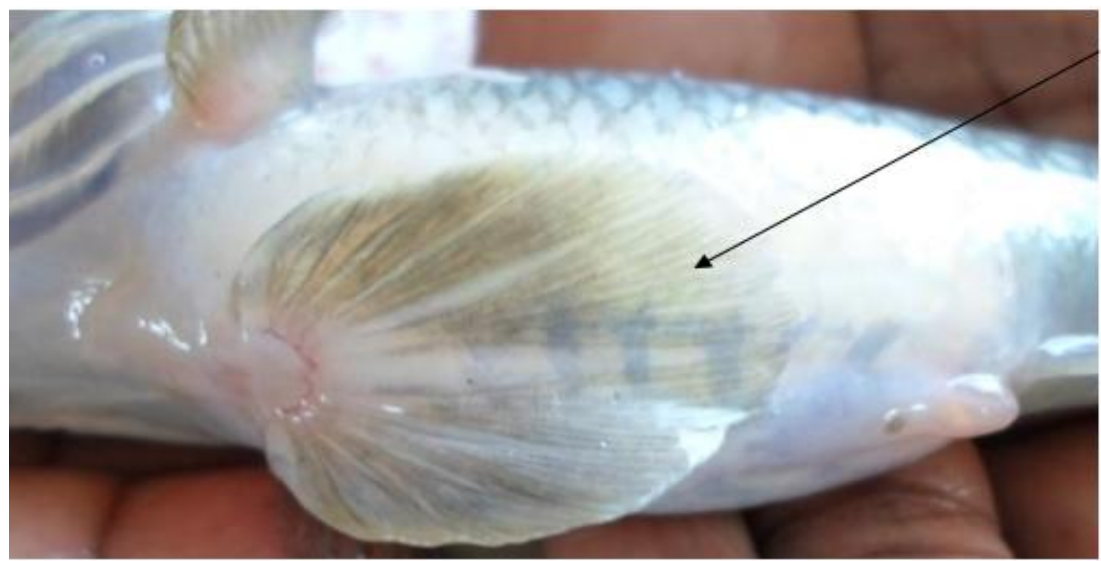

Soft and swollen

abdomen

Fig. 5. Soft and swollen abdomen of female gobi (G. giuris) 6h post second injection of PG

Table 2. Effects of different PG doses on the ovulation response of female gobi (G. giuris), and fertilization and hatching success of eggs

\begin{tabular}{|c|c|c|c|c|c|c|c|c|c|c|}
\hline \multirow{2}{*}{$\begin{array}{l}\text { Trial } \\
\text { and } \\
\text { Month }\end{array}$} & \multirow[t]{2}{*}{ Treatment } & \multicolumn{2}{|c|}{ Weight of brood fish (g) } & \multicolumn{2}{|c|}{$\begin{array}{l}\text { Dose of PG (mg/ } \\
\mathrm{kq})\end{array}$} & \multirow{2}{*}{$\begin{array}{l}\text { Latency } \\
\text { period } \\
\text { (h) }\end{array}$} & \multirow{2}{*}{$\begin{array}{l}\text { Ovulation } \\
\text { rate } \\
(\%)\end{array}$} & \multirow{2}{*}{$\begin{array}{l}\text { Fertilization } \\
\text { rate } \\
(\%)\end{array}$} & \multirow{2}{*}{$\begin{array}{l}\text { Incubation } \\
\text { period } \\
\text { (h) }\end{array}$} & \multirow{2}{*}{$\begin{array}{l}\text { Hatching } \\
\text { rate } \\
(\%)\end{array}$} \\
\hline & & Female & Male & Female & Male & & & & & \\
\hline Trial 1 & $\mathrm{~T}_{1}$ & $146.6 \pm 9.34$ & $284.25 \pm 8.26$ & 40 & 20 & \multirow[t]{3}{*}{ - } & 0 & 0 & - & No \\
\hline \multirow[t]{2}{*}{ (June ) } & $\mathrm{T}_{2}$ & $147.2 \pm 2.59$ & $281.80 \pm 9.65$ & 45 & 20 & & 0 & 0 & - & ovulation \\
\hline & $\mathrm{T}_{3}$ & $141.4 \pm 3.78$ & $276.8 \pm 8.53$ & 50 & 20 & & 0 & 0 & - & occurred \\
\hline \multirow{3}{*}{$\begin{array}{l}\text { Trial } 2 \\
\text { (July) }\end{array}$} & $\mathrm{T}_{1}$ & $141.60 \pm 6.11$ & $275.4 \pm 3.97$ & 6 & 3 & \multirow[t]{3}{*}{$25-35$} & $56.33 \pm 1.53^{c}$ & $51.33 \pm 1.54^{\mathrm{C}}$ & \multirow[t]{3}{*}{$35-48$} & $52.00 \pm 4.36^{\mathrm{C}}$ \\
\hline & $\mathrm{T}_{2}$ & $165.2 \pm 5.12$ & $276.00 \pm 6.44$ & 8 & 4 & & $82.67 \pm 2.52^{\mathrm{a}}$ & $83.33 \pm 3.79^{a}$ & & $81.67 \pm 3.21^{a}$ \\
\hline & $\mathrm{T}_{3}$ & $159.4 \pm 3.44$ & $278.00 \pm 7.45$ & 10 & 5 & & $75.33 \pm 1.53^{b}$ & $70.33 \pm 3.51^{b}$ & & $72.33 \pm 6.03^{b}$ \\
\hline \multirow{3}{*}{$\begin{array}{l}\text { Trial } 3 \\
\text { (August) }\end{array}$} & $\mathrm{T}_{1}$ & $168.40 \pm 5.03$ & $283.40 \pm 9.24$ & 6 & 3 & \multirow[t]{3}{*}{$25-35$} & $58.00 \pm 2.65^{c}$ & $53.67 \pm 4.04^{\mathrm{c}}$ & \multirow[t]{3}{*}{$35-48$} & $54.67 \pm 3.23^{c}$ \\
\hline & $\mathrm{T}_{2}$ & $172.2 \pm 7.43$ & $278.00 \pm 5.15$ & 8 & 4 & & $94.67 \pm 1.53^{a}$ & $92.33 \pm 2.52^{\mathrm{a}}$ & & $91.67 \pm 3.06^{a}$ \\
\hline & $\mathrm{T}_{3}$ & $173 \pm 3.74$ & $274.80 \pm 5.31$ & 10 & 5 & & $78.33 \pm 1.53^{\mathrm{b}}$ & $74.00 \pm 3.61^{\mathrm{b}}$ & & $73.67 \pm 5.13^{\mathrm{b}}$ \\
\hline
\end{tabular}

${ }^{*}$ For the female fish, the dose was divided into two volumes (1st dose $30 \%$ and 2 nd dose $\left.70 \%\right)$ and injected at $6 \mathrm{~h}$ interval, and the males were injected with
during 2 2nd injection to females. Mean values in the same column in each trial, having different superscripts are significantly different (P<0.05) 


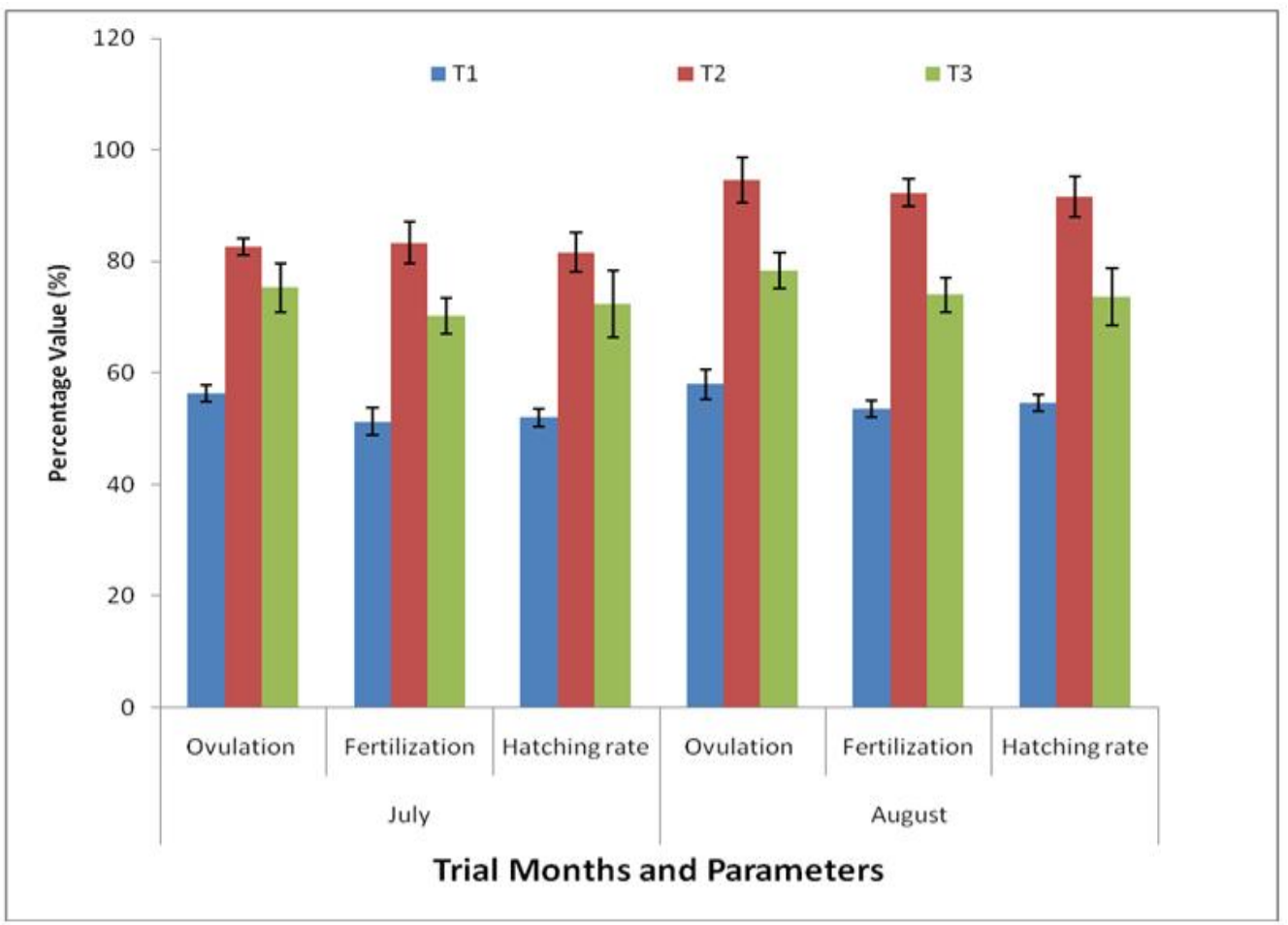

Fig. 6. Effects of different doses viz., $6 \mathrm{mg}\left(T_{1}\right), 8 \mathrm{mg}\left(T_{2}\right)$ and $10 \mathrm{mg}\left(T_{3}\right)$ of $P G / k g$ body weight of PG extract on induced breeding (ovulation, fertilization and hatching) of gobi (G. giuris).

Vertical bars of each parameter having different colours are significantly different $(P<0.05)$ with standard deviation (male fish was not considered in induced breeding)

some species with an aim to standardize the dose of PG for successful ovulation, there remains uncertainty among the doses reported by various workers. About the induced breeding of $G$. giuris, no information is available in Bangladesh or elsewhere in the world regarding the dose optimization and suitability of the inducing agents. So, it was felt extremely crucial to optimize a dose by which the induced breeding technique of the fish can be developed. However, very recently some of reproductive aspects of $G$. giuris were studied by Islam and Mollah [17], where the highest gonado-somatic index was observed in the month of July. They breed during the period of May to September with a peak in August. Having known this information, an experiment was conducted to find out a suitable dose of $P G$ for induction of ovulation in $G$. giuris during the months of June to August 2013. The induction of ovulation and spawning in gobi using $P G$ extract was done successfully. The PG doses of 40 to $50 \mathrm{mg} / \mathrm{kg}$ body weight was proved to be very high, which were selected on the basis of the preliminary work conducted by Islam and Mollah [17] to induce ovulation in the month of June. On the other hand, two breeding trials were conducted in July and August using $6 \mathrm{mg}\left(\mathrm{T}_{1}\right), 8 \mathrm{mg}\left(\mathrm{T}_{2}\right)$ and $10 \mathrm{mg}\left(\mathrm{T}_{3}\right) \mathrm{PG} / \mathrm{kg}$ body weight of fish, where ovulation rates were recorded as $56.33 \pm 1.53$, $82.67 \pm 2.52$ and $75.33 \pm 1.53 \%$ in July, and $58.00 \pm 2.65,94.67 \pm 1.53$ and $78.33 \pm 1.53 \%$ in August under the treatments $T_{1}, T_{2}$ and $T_{3}$, respectively.

In the present study, the highest average fertilization rate $(92.33 \pm 2.52 \%)$ was recorded during the month of August in $\mathrm{T}_{2}$ where G. giuris broods were injected with a dose of $8 \mathrm{mg} \mathrm{PG/kg}$ body weight, whereas the lowest value $(51.33 \pm 1.54 \%)$ was recorded during July in $T_{1}$, where the fishes were administered with $8 \mathrm{mg}$ PG/kg body weight. Similarly, the highest hatching was observed as $91.67 \pm 3.06 \%$ during the month of August in $\mathrm{T}_{2}$ and the lowest value was recorded as $52.00 \pm 4.36 \%$ during July in $T_{1}$. Incubation period ranged from $35-48 \mathrm{~h}$ in all treatments under the ambient water temperature of $27-29^{\circ} \mathrm{C}$. Though majority of the larvae were died within 7-8 days after hatching but they were 
survived when fed with tubificid worms and zooplankton. The fish treated with the dose of 8 $\mathrm{mg} \mathrm{PG/kg} \mathrm{body} \mathrm{weight} \mathrm{in} \mathrm{the} \mathrm{month} \mathrm{of} \mathrm{August}$ showed the best performance so far as the ovulation, fertilization and hatching rates were concerned, while the fish treated with $6 \mathrm{mg}$ $\mathrm{PG} / \mathrm{kg}$ body weight showed the lowest ovulation, fertilization and hatching rates of $G$. giuris eggs. Since fish of approximately similar size and maturity were used under the same management practices, the difference in the result obtained was only due to the variation in $P G$ doses. As different doses of PG were used, their effectiveness was found to be varied in case of ovulation, fertilization, hatching. When hormone optimization trials using three doses $(6,8,10 \mathrm{mg}$ $\mathrm{PG} / \mathrm{kg}$ body weight) were performed, the dose 8 $\mathrm{mg} \mathrm{PG/kg}$ body weight showed the best performance.

There are some factors responsible for the success of breeding. These are: good management, age and size of brood fish [18], feeding and manuring [19], doses of hormone used [20] and egg quality [19]. If the oocyte nuclei are found to be centrally located then such a fish would not respond to hormonal induced breeding treatment [21]. If the eggs are immature, fertilization does not occur. Pillay [22] opined that successful induced breeding depends on the appropriate dose of hormone administration; brood fish condition, sex ratio and even environmental conditions are equally important. It also depends on the maturation of fishes, especially the ripeness of oocytes in the female fish $[23,24]$.

The dose of hormone for induced breeding varies from species to species; some fishes need a very high dose, some species require a small dose and some require a moderate dose [25]. Islam et al. [26] used PG doses of $8 \mathrm{mg} / \mathrm{kg}$ body weight for female and $4 \mathrm{mg} / \mathrm{kg}$ body weight for male of Mystus vittatus and found $80 \%$ fertilization and $56 \%$ hatching rates. Khan and Mollah [14] induced Pangasius pangasius by injecting PG extract at the rate of $9,10,11$ and $12 \mathrm{mg} / \mathrm{kg}$ body weight, which resulted $100 \%$ ovulation and the best result was obtained in case of fertilization and hatching rate of eggs when $10 \mathrm{mg} / \mathrm{kg}$ body weight of $P G$ extract was used. Bhuiyan et al. [15] applied PG doses at the rate of 3, 6, 9, 12 and $15 \mathrm{mg} / \mathrm{kg}$ body weight, which induced $100 \%$ ovulation in Puntius gonionotus. They found that the dose of $6 \mathrm{mg} / \mathrm{kg}$ body weight was most efficient for induced breeding of $P$. gonionotus during the peak month of June. Saha et al. [27] worked on induced breeding of Thai koi, Anabas testudineus in different months of the breeding season under two sex ratios. They found better results in terms of fertilization (96.33\%), hatching $(89.67 \%)$ and survival $(80.33 \%)$ rates in mid-April to May for the sex ratio of 1:2 (female: male), using the PG extract at $12 \mathrm{mg} / \mathrm{kg}$ body weight of female and half of the quantity of female for the male. Kohinoor et al. [28] successfully used PG extract at the rate of $8-12 \mathrm{mg} / \mathrm{kg}$ body weight for female Anabas testudineus. Kohinoor and Zaher [29] also stated that $10-12 \mathrm{mg} / \mathrm{kg}$ body weight of female was the best in considering the fertilization and hatching rates. The doses of $P G$ extract for $G$. giuris were more or less similar to the dose used for $P$. pangasius, Puntius gonionotus, Thai koi and Anabas testudineus. On the other hand, Tan and Lam [30] administered HCG to ovulate marble gobi (Oxyeleotris marmorata) where over 90\% eggs were fertilized of which $>90 \%$ hatched subsequently and hatching time was extremely changeable, ranging from 2 to 5 days after fertilization at a temperature of $27^{\circ} \mathrm{C}$ where larvae did not survive for more than a few days. In the present study rate of fertilization and hatching time of is more or less similar of marble gobi except the inducing agent.

Mollah [13] used four doses of PG viz., 80, 100, 120 and $140 \mathrm{mg} / \mathrm{kg}$ body weight in female Rita rita and found that $100 \mathrm{mg} / \mathrm{kg}$ body weight was effective for induction of ovulation, but lower and higher doses such as 80 and $100 \mathrm{mg} \mathrm{kg}^{-1}$ body weight had no effect on ovulation. This indicates that lower and higher dose was unable to induce ovulation. Similar findings were obtained in case of $G$. giuris where higher dose of $P G$ such as 40 to $50 \mathrm{mg} \mathrm{kg}^{-1}$ body weight had no effect on ovulation. On the other hand, lower dose of 6 $\mathrm{mg} / \mathrm{kg}$ body weight was not found to be sufficient for inducing the ovulation in $G$. giuris. When lower and higher doses of PG were used, there was inhibitory loop or feedback or the inappropriate hormonal doses were not effective or enough to stimulate gonad.

The latency period available in the literature is 625 h for Channa punctatus [31], 22-25 h for Heteropneustes fossilis [32], $14 \mathrm{~h}$ for Puntius dorsalis [33], 16-20 h for Clarias gariepinus [34] and $30 \mathrm{~h}$ for $C$. stiriatus [35]. Average latency periods in case of $G$. giuris in the present study were recorded to be 25-35 $\mathrm{h}$ during July and August. Different environmental parameters such as temperature, rainfall, oxygen, thunder etc. 
may effect on fish breeding. There was enough rainfall and thunder during August, which might have enhanced the breeding performance as well as ovulation, fertilization and hatching of $G$. giuris.

The results obtained from the present study indicated that the induced spawning of G. giuris was successful, using different doses of PG extract and in all trials, better performances in terms of ovulation, fertilization, and hatching rates of $94.67 \pm 1.53,92.33 \pm 2.52$ and $91.67 \pm 3.06 \%$, respectively were found when used $8 \mathrm{mg} \mathrm{PG} \mathrm{kg}^{-1}$ body weight under the treatment $\mathrm{T}_{2}$.

\section{CONCLUSION}

Upon all considerations, injection of PG extract at a dose of $8 \mathrm{mg} \mathrm{PG/kg}$ body weight of female $G$. giuris in August showed better results. It was observed from the present investigation that the fertilization and hatching rates were commercially viable for the production of gobi (G. giuris) fish in captive condition. Overall, the present study concludes that induced breeding of gobi ( $G$. giuris) through $P G$ extract is successful, the findings of which would immensely be helpful towards the large-scale production of quality seeds for aquaculture production as well as conservation of this important fish species from extinction.

\section{DISCLAIMER}

The products used for this research are commonly and predominantly used products in our area of research and country. There is absolutely no conflict of interest between the authors and producers of the products because we do not intend to use these products as an avenue for any litigation but for the improvement of knowledge. Also, the research was not funded by the producing company rather it was funded by personal efforts of the authors.

\section{ETHICAL APPROVAL}

As international standard, written ethical permission has been collected and preserved by the authors.

\section{COMPETING INTERESTS}

Authors have declared that no competing interests exist.

\section{REFERENCES}

1. Bhuiyan AL. Fishes of Dacca. Asiatic Society Dacca. 1964;13:113-114.

2. Srivastava GJ. Fish of Eastern Uttar Pradesh. First Ed. Published by Vishwavidyalaya Prakashan, Varanasi, India. 1968;163.

3. Doha S. Investigation into the biology of the gobi, Glossogobius giuris (HamiltonBuchanan). Bangladesh J Zool. 1974;2:95-106.

4. Islam MN, Joadder MAR. Seasonal variation of the proximate composition of freshwater goby, Glossogobius giuris (Hamilton) from the river Padma. Pakistan J Biol Sci. 2005;8(4):532-536.

5. Ahmed ATA, Mustafa G, Alam MZ. Biochemical composition of seven species of gobi fish. J Asiat Soc. Bangladesh Sci. 1984;10:107-111.

6. Rahman AKM. Freshwater Fishes of Bangladesh. The Zoological Society of Bangladesh, Dhaka, Bangladesh. 2005;168-169.

7. Hoese DF. Radiation of Glossogobius giuris in freshwaters of the Indo-West Pacific. Proceedings of International Symposium on Systematics and Diversity of Fishes. 2008;11.

8. Rao PS, Rao LM. Sex ratio, fecundity, maturity and spawning details of Glossogobius giuris (Hamilton) from gosthan estuary near Visakhapatnam. ICFAI J Life Sci. 2007;1(1):16-29.

9. Islam MN. Eco-biology of freshwater gobi, Glossogobius giuris (Hamilton) of the river Padma in relation to its fishery: A review. J. Biol. Sci. 2004;4(6):780-793.

10. Joaddar MAR. Length-weight relationship and condition factor $\left(\mathrm{K}_{\mathrm{n}}\right)$ of gobi, Glossogobius giuris (Hamilton) from "Atrai River" in the northern part of Bangladesh. J. Fish Int. 2009;4(1):1-4.

11. Hoese DF. Gobidae. In Smith's Sea Fishes. Springer-Verlag, Berlin. 1986;774787.

12. Islam MN. Cannibalism of freshwater gobi, Glossogobius giuris (Hamilton) in relation to its size, sex and season from the river Padma. Univ J Zool, Rajshahi Univ. 2002;21:63-64.

13. Mollah MFA, Amin MR, Sarowar MN, Muhammadullah. First record of induced breeding of the riverine catfish Rita rita (Hamilton, 1822). Bangladesh J Agric Univ. 2008;6(2):361-366. 
14. Khan MHK, Mollah MFA. Further trials on Induced breeding of Pangasius pangasius (Hamilton) in Bangladesh. Asian Fish Sci. 2004;17:135-146.

15. Bhuiyan AS, Islam MK and Zaman $\mathrm{T}$. Induced spawning of Puntius gonionotus (Bleeker). J Biol Sci. 2006;14:121-125.

16. Bhuiyan AS, Musa ASM, Islam MK. Some observations on the induced spawning of Labeo rohita (Hamilton, 1822) by pituitary hormone injection. Bangladesh J Life Sci. 2008;20(1):89-94.

17. Islam MR, Mollah MFA. Morphological observation and PG-induced breeding of Glossogobius giuris (Hamilton 1822). J Sci Tech. 2013;11:171-180.

18. Bromage N. Brood stock management and seed quality general consideration. In: Brood Stock Management and Egg and Larval quality, Black Well Science Ltd. Oxford London, Edinburgh, Massachusetts, Victoria. 1998;1-24.

19. Springate J, Duston J, Baarker G. Brood stock management, fecundity, egg quality and timing of egg production in the rainbow trout. Aquaculture. 1985;100:141-166.

20. Nandeesha MC, Das SK, Nathaniel DE, Varghese TJ. Breeding carps in India. Asian Fish Soc. 1990;4:12-16.

21. Jhingran VG, Pullin RSV. A hatchery manual for the common, Chinese and Indian major carps. Asian Development Bank, International Center for Living Aquatic Resources Management, Manila, Philippines. 1990;1-58.

22. Pillay TVR. An aid to the identification of the catfishes of Bangladesh. Bangladesh $\mathrm{J}$ Zool. 1964;2(1):1-12.

23. Marimuthu $K$, Satthiyasilan $N$, Rahman MA, Arshad A, Raj MG, Arockiaraj J. Induced ovulation and spawning of African catfish Clarias gariepinus (Bloch) using ovaprim. J Environ Biotech Res. 2015;1(1):2-9.

24. Marimuthu K, Haniffa MA, Rahman MA. Spawning performance of native threatened spotted snakehead fish,
Channa punctatus induced with ovatide. Acta Ichthyol Piscat. 2009;39:1-5.

25. Hoq E. Bangladesher Chhoto Mach, Published by Graphic sign, 8 GKMC Shah Road, Chhoto Bazar, Mymensingh. 2006;20.

26. Islam SS, Shah MS, Rahi ML. Study of fecundity and induced breeding of Mystus vittatus. Bangladesh J Zool. 2011;39(2):205-212.

27. Saha A, Kabir MR, Ali MM. Breeding performances of Thai koi, Anabas testudineus (Bloch, 1972) in different months of the breeding season under two sex ratios. Bangladesh Res Pub J. 2009;2(4) 667-673.

28. Kohinoor AHM, Akhteruzzaman M, Hussain MG, Shah MS. Observation on the breeding of koi fish, Anabas testudineus (Bloch) in Bangladesh. Bangladesh J Fish. 1990;14(1-2):73-77.

29. Kohinoor AHM, Zaher M. Breeding of exotic koi (Anabas testudineus) at BFRI. Fisheries Newsletter, 2006;14(1):1-2.

30. Tan OKK, Lam TJ. Induced breeding and early development of the marble gobi (Oxyeleotris marmorata, Bleeker). Aquaculture. 2003;2:411-423.

31. Banerji SR. Hypophysation and life history of Channa punctaus (Bloch). J. Inland Fish Soc India. 1974;6:62-73.

32. Kohli MPS, Goswami UC. Spawning behavior of a freshwater air breathing Indian catfish Heteropneustes fossilis (Bloch). Matsya. 1987;12 180-183.

33. Rao C, Nagendra NR, Rahman KVK. An analysis of the fecundity in the Cyprinid fish Puntius dorsalis (Jardon). All India Seminar on Ichthyology. 1979;11.

34. Munshi JSD, Hughes GM. Air breathing fishes of India. Oxford and IBH Publishing Co. Pvt. Ltd. New Delhi. 1991;181-208.

35. Marimuthu K, Haniffa MA, Arockiraj J, Muruganandam M. Spawning and parental behavior in the induced breed murrels. Indian J Fish. 2001;48(4):409-411.

(c) 2021 Yeasmine et al.; This is an Open Access article distributed under the terms of the Creative Commons Attribution License (http://creativecommons.org/licenses/by/4.0), which permits unrestricted use, distribution, and reproduction in any medium, provided the original work is properly cited. http://www.sdiarticle4.com/review-history/64881 